\section{ECONOMICS}

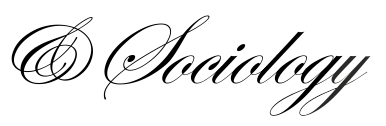

Hu, X., Ocloo, C. E., Akaba, S., \& Worwui-Brown, D. (2019). Effects of business to business e-commerce adoption on competitive advantage of small and medium-sized manufacturing enterprises. Economics and Sociology, 12(1), 8099. doi:10.14254/2071-789X.2019/12-1/4

\title{
EFFECTS OF BUSINESS-TO- BUSINESS E-COMMERCE ADOPTION ON COMPETITIVE ADVANTAGE OF SMALL AND MEDIUM-SIZED MANUFACTURING ENTERPRISES
}

\author{
Hu Xuhua, \\ School of Finance and Economics, \\ Jiangsu University, \\ Zhenjiang, Jiangsu Province, \\ PR China \\ E-mail:xubuabu@163.com
}

Ocloo Chosniel Elikem, School of Finance and Economics, Jiangsu University, Zhenjiang, Jiangsu Province, PR China

E-mail:ceocloo@atu.edu.gh ORCID: 0000-0003-4729-3093

Selorm Akaba, Department of Agricultural Economics and Extension, College of Agriculture and Natural Sciences, University of Cape Coast, Cape Coast, Ghana E-mail:sakaba@uccedu.gh ORCID: 0000-0001-90070472

\author{
David Worwui-Brown, \\ School of Business and \\ Management Studies, Accra \\ Technical University, \\ Accra, Ghana \\ E-mail:worwuibrown@yahoo.com
}

Received: July, 2018 1st Revision: November, 2018 Accepted: February, 2019
ABSTRACT. Business-to-business (B2B) e-commerce adoption has experienced rapid growth in recent times and has become one of the fastest technology adoptions among small and medium-sized enterprises (SMEs) in gaining and sustaining competitive advantage. A firm's resource endowments influence its B2B e-commerce adoption levels that lead to competitive advantage being gained in proportion to that level of adoption. A questionnaire survey was used to collect data for this research, 315 usable responses were obtained from owners and managers of small and medium-sized manufacturing firms in Ghana. This research uses structural equation modelling to examine how different levels of B2B e-commerce adoption affects different types of competitive advantage. The main finding is that SMEs can achieve cost reduction that helps them save on costs in their operational activities through higher levels of B2B e-commerce adoption. Implications of the research, its limitations and directions for future research are also discussed. 
DOI: $10.14254 / 2071-$

789X.2019/12-1/4

JEL Classification: L21, M15
Keywords: B2B e-commerce adoption, competitive advantage, SMEs, Ghana.

\section{Introduction}

Recent advances in technologies, fast global competition, and the increasing demand on the side of customers are forcing organizations to re-examine how they can exploit the benefits of information technology (IT) capabilities to gain competitive advantage. Business-toBusiness (B2B) e-commerce is becoming one of the fastest growing domains for information systems' application (IS)/IT. Literature in IT/IS fields have recognized that B2B e-commerce adoption is flourishing and most scholars predict that it would continue to expand faster than business-to -customer electronic commerce, or B2C (Sila, 2013). B2B e-commerce can assist SMEs in obtaining different competitive advantages over their rivals and improving their capabilities to compete with large firms at the world markets (Hamad, Elbeltagi, \& El-Gohary, 2018; Scupola, 2003).

The SMEs sector constitutes a vital part of the economies in both developed and developing countries. However, their role in developed nations is far more meaningful than in developing economies. SMEs in developed countries accounts for more than $90 \%$ of all enterprises and contributes almost $60 \%$ of jobs for the private sector (OECD, 2012). In developed countries, B2B e-commerce adoption has been the most successful strategy for growth of the e-commerce market (Elbeltagi, Hamad, Moizer, \& Abou-Shouk, 2016). Therefore, SMEs in developing nations needs more consideration regarding B2B e-commerce adoption to enable them compete globally and sustain their significant contributions to employment and gross domestic product. In Ghana, the majority of business establishments are SMEs, they are constituting about $92 \%$ of all businesses in the country. SMEs contribute about $70 \%$ of GDP and accounts for about $85 \%$ of the total employment in the manufacturing sector (Awiagah, Kang, \& Lim, 2016).

Theoretical perspective on the literature review indicates that most of the previous studies used to have rather broad and generic view on the B2B e-commerce adoption by SMEs (Lip-Sam \& Hock-Eam, 2011). Likewise, other scholars tried to measure the relationship between IT adoption and competitive advantage (Bhatt, Emdad, Roberts, \& Grover, 2010), whereas most of these studies excluded other competitive advantage related dimensions and focused only on a single competitive advantage construct (Gebauer \& Schober, 2006; Seongbae \& Silvana, 2014). The benefits obtainable from B2B e-commerce depends on the level of its adoption (Elbeltagi et al., 2016; Lefebvre, Lefebvre, Elia, \& Boeck, 2005). The degree to which SMEs are prepared to adopt B2B e-commerce is proportionate to the adoption advantages they attain (Hamad et al., 2018). Also, scholars have recognized different levels of e-commerce applications and adoption, for examples, (Abou-Shouk, Megicks, \& Lim, 2013; Ghobakhloo, Arias-Aranda, \& Benitez-Amado, 2011), however, how competitive advantages can be achieved at each level of IT adoption has been less pronounced in IT/IS literature.

This research uses structural equation modelling to determine the extent to which the levels of B2B e-commerce adoption can predict multiple dimensions of competitive advantage among manufacturing SMEs in Ghana. This research contributes to literature by investigating 
B2B e-commerce adoption levels and how they relate to multidimensional competitive advantage of the manufacturing SMEs in Ghana. Therefore, this current research has enriched the existing $\mathrm{B} 2 \mathrm{~B}$ e-commerce literature by means of providing better understanding of $\mathrm{B} 2 \mathrm{~B}$ ecommerce adoption behavior and its impact on competitive advantage. The findings established that there are different levels of B2B e-commerce and different competitive advantage gained at each level of its adoption.

The rest of the research proceeds as follows: the next section deals with the literature review, conceptual framework and hypotheses' development. After that, the research method, measurements and results are discussed. Finally, the article ends with conclusions.

\section{Literature review}

The literature that relates to B2B e-commerce adoption levels and competitive advantage provides the conceptual bases for this research. This research adopts the definition of B2B e-commerce that includes the use of the internet and web-technologies for conducting inter-organizational business transactions (Teo \& Ranganathan, 2004 ). The term B2B ecommerce has been interchangeably used with other phrases such as electronic business, electronic commerce and web technologies.

\subsection{Levels of B2B e-commerce adoption}

The conception of the growth models recognizes that IS, including B2B e-commerce in organizations, are not fixed but involves several levels of development. The use of e-commerce growth model is very vital in providing a holistic description of the stages or levels of B2B ecommerce (Lefebvre et al., 2005). Since the evolution of e-commerce, scholars have developed e-commerce growth models due to the growing relevance of IS within firms and their increasing role in global business (Elbeltagi et al., 2016; Teo \& Pian, 2003). Scholars have proposed different types or levels of e-commerce adoption in SMEs as shown in Table 1.

E-commerce model is a staged progression of usage that begins from simple initial adoption technology-based activities to an advanced degree of use of more complex and integrated technologies. The initial stage usually involves a simple static website that gives the firm an online presence to provide information about its products or services and contact details. Then followed by a dynamic online presence that allows a two-way communication channel between the firm and its suppliers and customers, permitting comments and feedback from the customers. Electronic transaction as the next stage is where firms have online order systems and online payments. This is the level where customers have the privilege to search, customized, choose and buy online. Electronic collaboration is the final stage, where all business operations with supply chain partners are integrated electronically. It is worth stating that most of these models did not consider the relations between the different levels of B2B ecommerce adoption and the different kinds of competitive advantage in SMEs, which is the main purpose of this research. The issue of how different levels of e-commerce adoption influences the different degree of competitive advantage gain is less pronounced in e-commerce literature. Likewise, Elbeltagi et al. (2016), proposed a four-stage growth model to study B2B e-commerce adoption among manufacturing SMEs in the USA and Egypt, but their model did not include basic B2B e-commerce application that has to do with adopters using e-mail. This current research adapts Elbeltagi et al. (2016) B2B e-commerce adoption model, however, considers basic B2B e-commerce applications like the use of e-mail for business purposes. 


\subsection{Competitive advantage}

The creation of value is the landmark of any definition associated with competitive advantage (Pilinkiene, Kurschus, \& Auskalnyte, 2013). Competitive advantage reflects a firm's capability to create a secured position over its competitors as a result of a critical business decision (Hazen \& Byrd, 2012). Competitive advantage is experienced by a company when its operations in the industry or market creates economic worth and provides customers with higher values, by either selling at a lower prices or by offering unique benefits that offset a higher price than competitors for the same benefits (Marinagi, Trivellas, \& Sakas, 2014; Wagner, 2006). Taking into account the growing level of competition in most industries, adoption of IT has become one area that has been linked to competitive advantage for SMEs.

IT is one of the critical resources that can be utilized by SMEs to gain competitive advantage, and therefore, can support the firm's strategy to achieve a competitive advantage against their rivals and to remain competitive in both the domestic and international markets. Several extant investigations (Hazen \& Byrd, 2012; Marinagi et al., 2014; Pavic, Koh, Simpson, $\&$ Padmore, 2007) have identified the relationship between IT adoption and competitive advantage. These researches assert that IT is not only the weapon that can achieve competitive advantage but would equally help in sustaining and promoting such benefits. A study by Hazen and Byrd (2012) found that IT adoption created competitive advantage through growth in levels of efficiency and effectiveness. Likewise, a study conducted by Hamad et al. (2018) confirmed that B2B e-commerce adoption helped Egyptian SMEs to gain competitive advantage through enhancing business efficiency, lowering costs, providing new and better products and services, increased market share and sales. Some scholars upheld that IT adoption enables SMEs to attain competitive advantage through many paths (Hamad et al., 2018; Hazen \& Byrd, 2012); however many prior e-commerce studies have not adequately distinguished between the types of competitive advantages obtained by the different levels of B2B e-commerce adoption.

This research examines competitive advantage and its relation to IT adoption in terms of cost reduction, growth, differentiation and innovation. First, cost reduction is one of the main advantages achieved by SMEs for adopting and implementing IT. Besides, it has been found that adopting internet technologies can dramatically save costs on obtaining, processing and transmitting information, therefore, changing the way organizations do business (Guarda, Augusto, \& Silva, 2012; Teo \& Pian, 2003). Likewise, other researches have revealed that the adoption of internet technologies reduces the cost of advertising, marketing and sales of products and services, operating costs and inventory costs (Hamad et al., 2018; Krell \& Matook, 2009).

Second, growth is the means of enhancing business efficiency (Teo \& Pian, 2003). IT adoption affects a SMEs' growth ability by increasing its scope and extending its core business through market penetration and development (Elbeltagi et al., 2016; Teo \& Pian, 2003). The adoption of technology can help SMEs' increase market share and effectively expand its geographical markets domestically and globally (Bhatt et al., 2010; N'Da, Bergeron, \& Raymond, 2008). Internet technology increases a firm's sales and revenue and increases customer satisfaction that enables an organization to form and develop customers' intimacy.

Third, differentiation is a way of enhancing the credibility and prestige of the firm by offering unique value to its customers and help the firm distinguish its products and services from its rivals (Hamad et al., 2018; Teo \& Pian, 2003). The adoption of technology assists a SMEs to differentiate itself not through price only but also through product innovation, customer service, and shorter time to market. Likewise, technology adoption helps firms to provide new products and services, and offers customers the liberty to customize products and services, thus boosting its differentiation advantage (Hamad et al., 2018; Lumpkin, Droege, \& 
Dess, 2002). Moreover, organizations can use websites to reinforce their brand image, the distinction of which can help build up customer loyalty, which is considered as one of the most powerful weapons in attracting capturing market (N'Da et al., 2008; Teo \& Pian, 2003).

Finally, innovation as one of the components of competitive advantage could generate effects on one or more links to the industry or value chain. This generally covers product and process research and development (R\&D), marketing, sales and distribution (Marinagi et al., 2014; Teo \& Pian, 2003). The effect of technology adoption on innovation ensures the gathering of information about customers' requirement from the websites can easily help in the generation of new product ideas. It also enhances collaboration network within the organizations and between the organizations and its trading partners. The close relationship among suppliers along the supply chain can provide opportunities to enhance the product-distribution process. All of these competitive advantages could be improved by using B2B e-commerce.

Table 1. Levels of electronic commerce adoption models

\begin{tabular}{|c|c|c|c|c|c|c|}
\hline Authors/Year & Stage 0 & Stage 1 & Stage 2 & Stage 3 & Stage 4 & Stage 5 \\
\hline $\begin{array}{l}\text { Abou-Shouk } \\
\text { et al. (2013) }\end{array}$ & & $\begin{array}{l}\text { Static web } \\
\text { presence }\end{array}$ & $\begin{array}{l}\text { Interactive } \\
\text { online } \\
\text { presence }\end{array}$ & $\begin{array}{l}\text { Electronic } \\
\text { transaction }\end{array}$ & $\begin{array}{l}\text { Electronic } \\
\text { integration }\end{array}$ & \\
\hline $\begin{array}{l}\text { Al-Somali, } \\
\text { Gholami, and } \\
\text { Clegg (2011) }\end{array}$ & & $\begin{array}{l}\text { Non-interactive } \\
\text { electronic } \\
\text { commerce }\end{array}$ & $\begin{array}{l}\text { Interactive } \\
\text { electronic } \\
\text { commerce }\end{array}$ & $\begin{array}{l}\text { Stabilized } \\
\text { electronic } \\
\text { commerce }\end{array}$ & & \\
\hline $\begin{array}{l}\text { Chen and } \\
\text { McQueen } \\
(2008)\end{array}$ & & $\begin{array}{l}\text { Internet search } \\
\text { and e-mail }\end{array}$ & $\begin{array}{l}\text { Online } \\
\text { marketing }\end{array}$ & $\begin{array}{l}\text { Online } \\
\text { ordering }\end{array}$ & $\begin{array}{l}\text { Online } \\
\text { transactions }\end{array}$ & \\
\hline $\begin{array}{l}\text { Rahayu and } \\
\text { Day (2017) }\end{array}$ & $\begin{array}{l}\text { No } \\
\text { internet/no } \\
\text { e-mail }\end{array}$ & $\begin{array}{l}\text { e-mail but no } \\
\text { websites }\end{array}$ & $\begin{array}{l}\text { Static } \\
\text { websites }\end{array}$ & $\begin{array}{l}\text { Interactive } \\
\text { website but no } \\
\text { transactions }\end{array}$ & $\begin{array}{l}\text { Websites } \\
\text { with } \\
\text { transactions }\end{array}$ & \\
\hline $\begin{array}{l}\text { Beck, } \\
\text { Wigand, and } \\
\text { Konig (2005) }\end{array}$ & & $\begin{array}{l}\text { Online } \\
\text { advertising }\end{array}$ & Online sales & $\begin{array}{l}\text { Online } \\
\text { procurement }\end{array}$ & $\begin{array}{l}\text { EDI with } \\
\text { suppliers } \\
\text { and } \\
\text { customers }\end{array}$ & \\
\hline $\begin{array}{l}\text { Elbeltagi et al. } \\
\text { (2016) }\end{array}$ & & $\begin{array}{l}\text { Electronic } \\
\text { information } \\
\text { search and } \\
\text { creation }\end{array}$ & $\begin{array}{l}\text { Simple } \\
\text { electronic } \\
\text { transactions }\end{array}$ & $\begin{array}{l}\text { Complex } \\
\text { electronic } \\
\text { transaction }\end{array}$ & $\begin{array}{l}\text { Electronic } \\
\text { collaboration }\end{array}$ & \\
\hline $\begin{array}{l}\text { Rao, Metts, } \\
\text { and Mora } \\
\text { Monge (2003) }\end{array}$ & & $\begin{array}{l}\text { Presence on the } \\
\text { web }\end{array}$ & Portals & $\begin{array}{l}\text { Transaction } \\
\text { integration }\end{array}$ & $\begin{array}{l}\text { Enterprise } \\
\text { integration }\end{array}$ & \\
\hline $\begin{array}{l}\text { Molla and } \\
\text { Licker (2005) }\end{array}$ & $\begin{array}{l}\text { Not } \\
\text { connected } \\
\text { to the } \\
\text { internet }\end{array}$ & $\begin{array}{l}\text { Internet with e- } \\
\text { mails }\end{array}$ & Static web & $\begin{array}{l}\text { Interactive } \\
\text { web presence }\end{array}$ & $\begin{array}{l}\text { Transactive } \\
\text { web }\end{array}$ & $\begin{array}{l}\text { Integrated } \\
\text { web }\end{array}$ \\
\hline $\begin{array}{l}\text { Bingley and } \\
\text { Burgess } \\
(2012)\end{array}$ & & $\begin{array}{l}\text { Communicators } \\
\text { (e-mail) }\end{array}$ & $\begin{array}{l}\text { Information } \\
\text { provision } \\
\text { (websites) }\end{array}$ & $\begin{array}{l}\text { Transaction } \\
\text { (online } \\
\text { statistics) }\end{array}$ & & \\
\hline
\end{tabular}

Source: Authors' compilation

\subsection{Research framework}

The purpose of this research is to examine how the different levels of B2B e-commerce in manufacturing SMEs affect the different types of competitive advantage in Ghana. The conception of the growth models recognizes that information technology adoption, including 
B2B e-commerce in organizations, is not fixed but involves some levels of progression. Ecommerce growth model is referred to as "stages or levels from an initial state to maturity to help organizations assess as-is situations, to guide development initiatives, and to control progress and the sophistication of e-commerce use" (Al-Ghamdi Alfarraj, \& Bahadad, 2014; Rahayu \& Day, 2017). Therefore, e-commerce growth models relate to sequential levels of ecommerce adoption and that the subsequent stage is better than the previous stage. Even though the evolution is described sequentially, there is no necessity for a business to start from the initial phase and that organizations can start from any stage. The use of e-commerce growth models is very vital in providing a holistic description of the various factors that may influence different B2B e-commerce adoption levels. Scholars used stages/levels of growth models to describe organizations' use of IT (Al-Ghamdi, Alfarraj, \& Bahadad, 2014). Along with the internet revolution in the 1990s, e-commerce development stages/levels emerged and had been rapidly and increasingly diffused among individuals and organizations. Some studies investigated different aspects of e-commerce adoption focusing on the individual and organizational level.

For SMEs, Information technology (IT) is one of the areas linked to competitive advantage. One goal of using IT is to support the organization's survival by employing internet technologies to keep ahead of competitors and to differentiate one's position in the world market. Therefore, the organization's management often considers IT as providing an opportunity to strengthen their competitive advantage (Andrew \& Malik, 2016; Elbeltagi et al., 2016; Xu \& Quaddus, 2013). IT is one of the critical resources that can be utilized by SMEs to gain competitive advantage, and therefore, can support the firm's strategy to achieve a competitive advantage against their rivals and to remain competitive in both the domestic and international markets (Abdelkader \& Abed, 2016; Breznik, 2012). Figure 1 shows the research framework, which is followed by five main hypotheses.

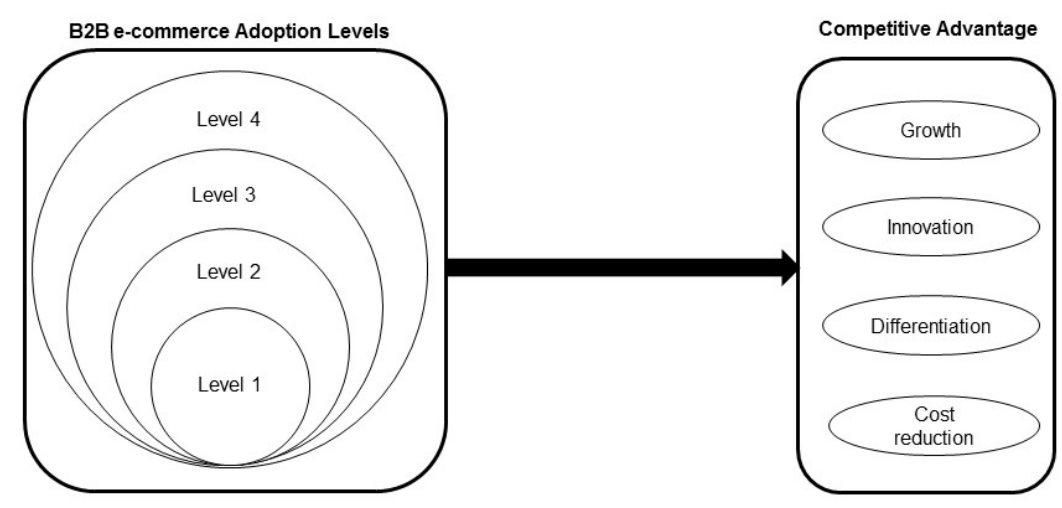

Figure 1. The research framework

The use of e-commerce growth model is significant to have a holistic explanation of the factors that may affect different levels of e-commerce. According to Zandi (2013), the use of growth e-commerce model allows firms to assess and determine the level of e-commerce that they currently use and compare it with the levels of growth described in the model. It is widely accepted that IT plays a significant role in creating and sustaining competitive advantage (Porter, 1985, Belton, 2017). Moraisa, Piresa, and Gonçalvesb (2012) suggested the use of ecommerce maturity models in SMEs in order to have a comprehensive understanding for decision makers in planning, deciding and implementing the appropriate level of B2B ecommerce that meets their SMEs needs. This can be done by identifying the competitive advantage associated with the levels of B2B e-commerce growth models. Base on the above 
concepts and framework on the nexus of B2B e-commerce adoption and SMEs' competitive advantage, the following hypotheses were formulated:

H1. The first level of B2B e-commerce adoption significantly affects SMEs' competitive advantage.

H2. The second level of B2B e-commerce adoption significantly affects SMEs' competitive advantage.

H3. The third level adoption of B2B e-commerce significantly affects SMEs' competitive advantage.

H4. The fourth level adoption of B2B e-commerce significantly affects SMEs' competitive advantage.

H5. The higher the level of B2B e-commerce an SME adopts, the higher the level of competitive advantage it gains.

\section{Methodological approach}

\subsection{Sampling and data collection}

A questionnaire survey was used to gather data from Ghanaian SME owner or managers from the manufacturing sector. SMEs with less than 100 employees were considered based on the classification of businesses in Ghana by the Regional Project on Enterprise Development. The study randomly selected 1,124 Ghanaian manufacturing SMEs as the sample frame (from the government of Ghana via the National Board for Small Scale Industries, Registrar General Department and Association of Ghana Industries databases). The data provided by these agencies were accessed through their websites. Further, using a systematic random procedure, a representative sample of 648 manufacturers with websites were chosen, using the aggregation of product type and geographic locations as stratification criteria. Geographic locations were across four regions out of the ten regions in Ghana, namely; Greater Accra, Western, Ashanti, and Eastern Regions. The sampling frame is a cross-section of six industries, namely: construction and electricals, polymers and rubbers, textiles and clothing, pharmaceuticals and chemicals, food processing and beverages, and wood, tissues and paper products, in order to increase generalizability. The researchers validated a total of 315 responses that were free of missing data (an effective response rate of $48.6 \%$ ).

The questionnaire consisted of a series of Likert-type (scale of $1-5$, from strongly disagree to strongly agree) statements informed from the literature review; however, this research modified several items to fit the context of the present study. The level of B2B ecommerce adoption was measured using fifteen (15) electronic business processes (eBPs) that categorized the four levels of B2B e-commerce adoption. The eBPs were adapted from Elbeltagi et al. (2016) and modified based on the researchers' view and pilot study. The proposed four levels of B2B e-commerce adoption include, electronic information (Level 1), electronic interaction (Level 2), electronic transaction (Level 3) and electronic collaboration (Level 4) as depicted in Appendix A. For competitive advantage constructs (growth, innovation, differentiation and cost reduction), the research used familiar measures drawn from extant investigations as shown in Table 2.

More than 53\% of the responses were from Chief Executive Officers/owners, and the rest were from managers in charge of operations and IT. Based on the Regional Project on Enterprise Development of Ghana classification, 60\% of the firms could be classified as "medium businesses". Besides, $71 \%$ of the respondents have been in business for more than ten years. 
Table 2. The measurement scale for competitive advantage

\begin{tabular}{|c|c|c|c|}
\hline Constructs & Items & Descriptions of items & Sources \\
\hline \multirow{6}{*}{$\begin{array}{l}\text { Cost reduction } \\
(\text { Cost })\end{array}$} & Cost1 & Reduce costs in document publications & \multirow{6}{*}{$\begin{array}{l}\text { Teo and Pian (2003); } \\
\text { Lederer, Mirchandani, } \\
\text { and Sims (1997); } \\
\text { Elbeltagi et al. (2016); } \\
\text { N'Da et al. (2008) }\end{array}$} \\
\hline & Cost 2 & Reduce costs in marketing & \\
\hline & Cost3 & Reduce costs in advertising & \\
\hline & Cost4 & Reduce costs in information distribution & \\
\hline & Cost5 & Reduce costs in communication & \\
\hline & Cost6 & Reduce costs in operational activities & \\
\hline \multirow{6}{*}{$\begin{array}{l}\text { Growth } \\
\text { (Grow) }\end{array}$} & Grow1 & Enhance business efficiency & \multirow{6}{*}{$\begin{array}{l}\text { N'Da et al. (2008); } \\
\text { Lederer et al. (1997); } \\
\text { Elbeltagi et al. (2016) }\end{array}$} \\
\hline & Grow2 & Increase market share & \\
\hline & Grow3 & Increase customer satisfaction & \\
\hline & Grow4 & Increase in sales and revenue & \\
\hline & Grow5 & Access to new markets & \\
\hline & Grow6 & Better achieve organizational goals & \\
\hline \multirow{6}{*}{$\begin{array}{l}\text { Innovation } \\
\text { (Inno) }\end{array}$} & Inno1 & Allow other applications to be developed faster & \multirow{6}{*}{$\begin{array}{l}\text { Lederer et al. (1997); } \\
\text { Teo and Pian (2003) }\end{array}$} \\
\hline & Inno 2 & Better coordinate business operations & \\
\hline & Inno3 & Change the way firm conduct business & \\
\hline & Inno4 & Shorten the period for product development & \\
\hline & Inno5 & $\begin{array}{l}\text { Allow previously infeasible applications to be } \\
\text { implemented }\end{array}$ & \\
\hline & Inno6 & Responding more quickly to change & \\
\hline \multirow[t]{6}{*}{$\begin{array}{l}\text { Differentiation } \\
\text { (Diff) }\end{array}$} & Diff1 & $\begin{array}{l}\text { Provide better and new products/services to the } \\
\text { customer }\end{array}$ & \multirow{6}{*}{$\begin{array}{l}\text { Elbeltagi et al. (2016); } \\
\text { Lederer et al. (1997); } \\
\text { N'Da et al. (2008); } \\
\text { (Teo \& Pian, 2003) }\end{array}$} \\
\hline & Diff2 & Provide easier customer access to information & \\
\hline & Diff3 & Speeding up transactions & \\
\hline & Diff4 & Enhance brand distinguishability & \\
\hline & Diff5 & Enhance the credibility and prestige of the firm & \\
\hline & Diff6 & Provide customized products/services & \\
\hline
\end{tabular}

Source: Authors' compilation

\section{Data analysis and results}

The hypotheses are tested using partial least squares structural equation modelling (PLS-SEM) and through the SmartPLS software package (Ringle, Wende, \& Becker, 2015). PLS-SEM is considered most appropriate for this research since it allows the simultaneous estimation of multiple causal relationships between one or more independent variables and one or more dependent variables (Hair, Ringle, \& Sarstedt, 2011) and has the capability to handle reflective and formative constructs (Hair, Hult, Ringle, \& Sarstedt, 2016). PLS-SEM is a wellestablished variance-based SEM technique that has recently gained acceptance across many disciplines including information systems (Benitez, Llorens, \& Fernandez, 2015). Likewise, PLS-SEM avoids the challenges associated with small sample size and has less strict assumptions of normality distribution and error terms. Finally, being a non-parametric technique, the bootstrapping technique used in PLS-SEM can construct confidence intervals of estimates for hypothesis testing even though the sample size employed may be small. 


\subsection{Measurement Model}

The measurement model was assessed through tests of individual item loadings, internal consistency reliability, convergent validity, discriminate validity, and variance inflation factors of the research instruments, using recommended guidelines (Chin, 2010; Hair et al., 2011). In this research, the measurement model was tested in two parts as the model comprise both reflective and formative latent variables. First, the measurement was tested for levels of adoption, being considered as formative latent constructs. The significance and relevance of each formative indicator were measured by weight statistics (Hair et al., 2016). Therefore, formative construct items who weights do not support or meet this criterion have to be excluded. Also, PLS provides variance inflation to validate the items of constructs. The researchers applied the bootstrapping algorithm with 5000 resample to determine the level of significance of each indicator weight. As presented in Table 3, all weights are substantial and significant at the 0.001 level, and the VIFs were below the cut-off point of 3.3 (Hair et al., 2011).

Table 3. Multicollinearity of the formative constructs (B2B e-commerce adoption levels)

\begin{tabular}{lllcc}
\hline Formative constructs & Indicators & Weights & S.E & VIF \\
\hline Level 1: Electronic information & Level1A & $0.310^{* * *}$ & 0.017 & 2.535 \\
& Level1B & $0.262^{* * *}$ & 0.015 & 2.285 \\
& Level1C & $0.286^{* * *}$ & 0.021 & 1.808 \\
& Level1D & $0.319^{* * *}$ & 0.018 & 2.087 \\
& & & & \\
\hline Level 2: Electronic interaction & Level2A & $0.259^{* * *}$ & 0.026 & 1.424 \\
& Level2B & $0.299^{* * *}$ & 0.024 & 1.552 \\
& Level2C & $0.347 * * *$ & 0.014 & 2.672 \\
& Level2D & $0.325^{* * *}$ & 0.015 & 2.406 \\
& & & & \\
\hline Level 3: Electronic transaction & Level 3A & $0.317^{* * *}$ & 0.024 & 1.701 \\
& Level3B & $0.455^{* * *}$ & 0.023 & 2.000 \\
& Level3C & $0.381^{* * *}$ & 0.017 & 2.263 \\
\hline Level 4: Electronic collaboration & & & & \\
& Level4A & $0.298^{* * *}$ & 0.016 & 2.138 \\
& Level4B & $0.271^{* * *}$ & 0.016 & 2.115 \\
& Level4C & $0.374^{* * *}$ & 0.020 & 2.254 \\
& Level4D & $0.275^{* * *}$ & 0.019 & 2.118 \\
\hline
\end{tabular}

$* * * \mathrm{p}<0.001, \mathrm{~S} . \mathrm{E}=$ Standard error, VIF $=$ Variance inflation factor

Source: Authors' data

Second, the measurements were tested for competitive advantage - cost reduction, growth, differentiation and innovation, considered reflective latent variables. Indicator reliability was evaluated by examining if construct-to-item loadings were above the threshold of 0.70. The result identified some poor item loadings; cost reduction two items (Cost1, Cost6), two items for growth (Grow1, Grow6), one item for innovation (Inno6) and two items for differentiation (Diff3, Diff4), and these items were removed from the analysis as recommended by Hair et al. (2011). All the remaining reflective items had loadings above 0.70. Both Cronbach's alpha and composite reliability for the competitive advantage dimensions exhibited acceptable internal consistency reliability, exceeding the recommended 0.70 (Fornell \& Larcker, 1981). Also, Dijkstra-Henseler's rho, the only current consistent reliability measure for PLS constructs scores (Henseler, Hubon, \& Ray, 2016) has loadings above 0.70, thus, emphasizing the reliability of the measurement model. Convergent validity was tested by 
examining whether the average variance extracted (AVE) was above the threshold of 0.50 (Fornell \& Larcker, 1981). All the AVE values greatly exceeded the threshold (see Table 4). Discriminant validity was measured through two methods. First, the Fornell and Larcker (1981) criterion is used to test whether the square root of a construct's AVE is higher than the correlations between it and any other construct within the model. Second, the factor loadings of an item on its associated construct should be greater than the cross-loadings of another nonconstruct item on that construct (Farrell, 2010) as evidenced in Table 4. These results support the appropriateness of reflective measures and propose that all items are good indicators for their respective latent variables.

Table 4. Measurement model of the reflective construct (Competitive advantage)

\begin{tabular}{llllll}
\hline Construct & $\begin{array}{l}\text { Cronbach's } \\
\text { alpha }\end{array}$ & rho_A & CR & AVE & SQRT AVE \\
\hline Level 1 & - & - & - & - & - \\
Growth & 0.800 & 0.809 & 0.870 & 0.626 & 0.791 \\
Innovation & 0.875 & 0.885 & 0.908 & 0.665 & 0.816 \\
Differentiation & 0.825 & 0.860 & 0.883 & 0.654 & 0.809 \\
Cost reduction & 0.790 & 0.808 & 0.863 & 0.612 & 0.782 \\
\hline Level 2 & - & & & & \\
Growth & 0.800 & 0.816 & 0.869 & 0.625 & 0.791 \\
Innovation & 0.875 & 0.889 & 0.908 & 0.664 & 0.815 \\
Differentiation & 0.825 & 0.844 & 0.884 & 0.655 & 0.810 \\
Cost reduction & 0.790 & 0.802 & 0.864 & 0.613 & 0.785 \\
& & & & & \\
\hline Level 3 & - & - & - & - & - \\
Growth & 0.800 & 0.810 & 0.870 & 0.626 & 0.791 \\
Innovation & 0.875 & 0.907 & 0.906 & 0.661 & 0.813 \\
Differentiation & 0.825 & 0.868 & 0.882 & 0.653 & 0.808 \\
Cost reduction & 0.790 & 0.798 & 0.865 & 0.614 & 0.784 \\
& & & & & \\
\hline Level 4 & - & - & - & - & \\
Growth & 0.800 & 0.817 & 0.868 & 0.625 & 0.791 \\
Innovation & 0.825 & 0.882 & 0.909 & 0.666 & 0.816 \\
Differentiation & 0.875 & 0.853 & 0.883 & 0.654 & 0.809 \\
Cost reduction & 0.790 & 0.804 & 0.862 & 0.615 & 0.783 \\
\hline
\end{tabular}

Note: CR: composite reliability, AVE: average variance extracted, SQTR AVE: squared AVE Source: Authors' data

\subsection{Structural Model}

The structural model was assessed by examining the coefficient of determination $\left(\mathrm{R}^{2}\right)$ values, predictive relevance (Stone-Geisser $\mathrm{Q}^{2}$ ) and the effect size $\left(f^{2}\right)$ of path coefficients. The research model and hypothesized relationships were estimated using 1000 iterations of the bootstrapping technique, and the significance of each structural path or estimates (t-statistics) was obtained by conducting a bootstrap algorithm with 5000 resamples. Four models were tested to examine how the four different levels of B2B e-commerce adoption affected competitive advantage of the Ghanaian manufacturing SMEs. 


\subsubsection{Structural Model for Level 1}

The level 1 concentrates on the adoption of electronic information by the SMEs. For instance, the ability of the SMEs to provide basic information about the firm, promote the firm's product and services, communicating and responding with customers via e-mails. As posited by Andrew and Malik (2016), technology adoption not only reduces information distribution time but also reduces product cycle time. Besides, it has been found that adopting internet technologies can dramatically save costs on obtaining, processing and transmitting information, therefore, changing the way organizations do business (Abdelkader \& Abed, 2016; Xu \& Quaddus, 2013). The levels of adoption of electronic information were therefore modelled and presented in Figure 2. Regarding Level 1, it was found that this level significantly and positively affected growth $(\beta=0.512, t=15.207, p<0.001)$, innovation $(\beta=0.400, t=10.815$, $\mathrm{p}<0.001)$, differentiation $(\beta=0.428, \mathrm{t}=9.367, \mathrm{p}<0.001)$, and cost reduction $(\beta=0.466, \mathrm{t}=$ 10.283 , $\mathrm{p}<0.001$ ), therefore supporting H1. For $\mathrm{R}^{2}$, it was found that the level of adoption explained $26.2 \%$ of the variance in growth, $16.0 \%$ of that in innovation, $18.3 \%$ of that in differentiation, and $21.7 \%$ of that in cost reduction as illustrated in Figure 2. Also, the research's statistical analysis results show that the $f^{2}$ for growth, innovation, differentiation and cost of reduction are $0.355,0.191,0.224$ and 0.278 respectively. These indicate that Level 1 adoption has a large effect on growth and medium effect on innovation, differentiation and cost reduction respectively. Results of the blindfolding procedure show that at Level 1 of adoption, growth $\left(Q^{2}=0.115\right)$, innovation $\left(Q^{2}=0.097\right)$, differentiation $\left(Q^{2}=0.110\right)$ and cost reduction $\left(Q^{2}=0.122\right)$ respectively have a satisfactory predictive relevance (Henseler, Ringle, \& Sinkovics, 2009).

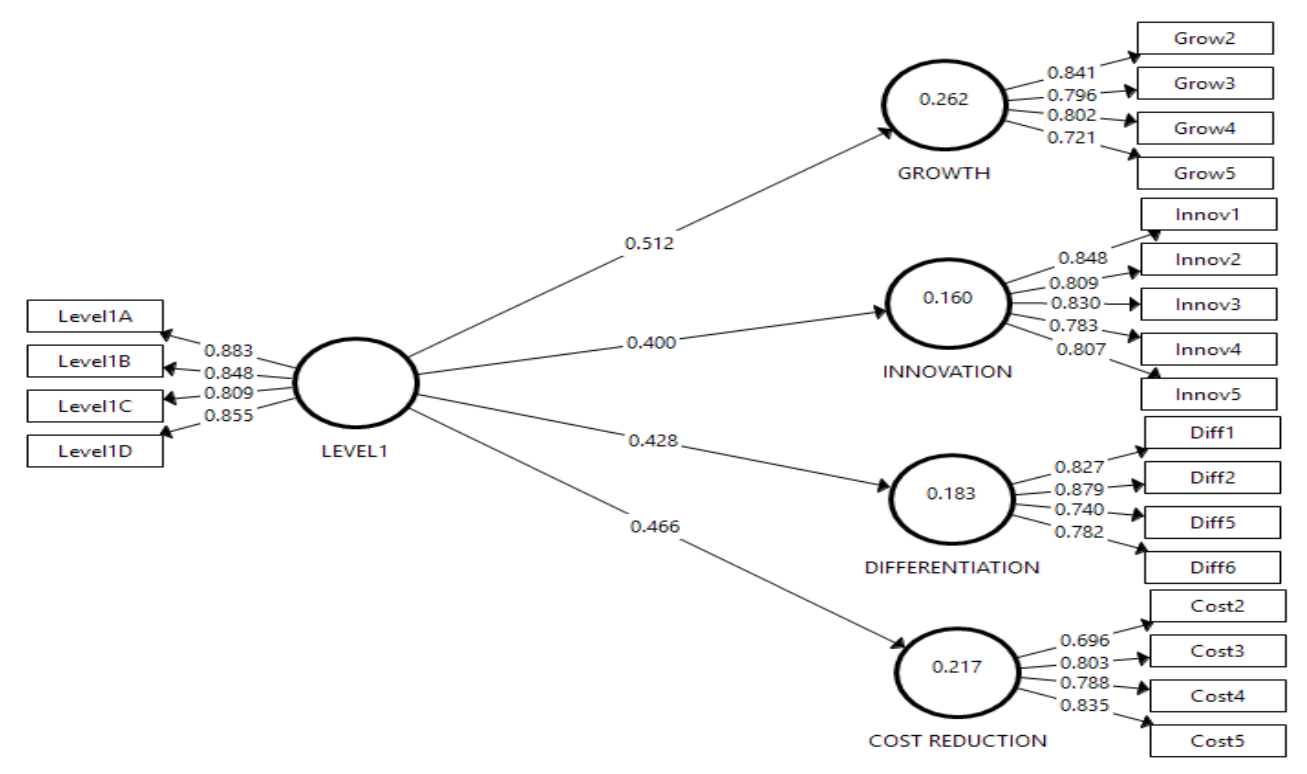

Figure 2. Structural model of Level 1

\subsubsection{Structural Model of Level 2}

Level 2 focused on electronic interaction, which comprised of responding to enquiries and feedbacks, placing and receiving orders, and offering after-sales service through electronic media. As affirmed by other researches, adoption of electronic technologies reduces costs of advertising, marketing and sales of products and services, operating costs and inventory costs 
(Abdelkader \& Abed, 2016; Hamad et al., 2018; Krell \& Matook, 2009). The adoption of electronic technology assists SMEs to differentiate itself by responding to different calibre of customers through product innovation, provision of new products and services and offers customers the liberty to customize products and services to boost the firms' differentiation advantage (Andrew \& Malik, 2016; Hamad et al., 2018). The result (Figure 3) show a significant positive effect on growth $(\beta=0.520, \mathrm{t}=16.042, \mathrm{p}<0.001)$, innovation $(\beta=0.381$, $\mathrm{t}=9.492, \mathrm{p}<0.001)$, differentiation $(\beta=0.464, \mathrm{t}=11.106, \mathrm{p}<0.001)$, and cost reduction $(\beta=$ $0.542, \mathrm{t}=14.465, \mathrm{p}<0.001)$, which supported $\mathrm{H} 2$. Also, the results for $\mathrm{R}^{2}$ revealed that the level of adoption explained $27.1 \%, 14.5 \%, 21.5 \%$, and $29.7 \%$ of the variance in growth, innovation, differentiation and cost reduction respectively, as depicted in Figure 3. Regarding the $f^{2}$, the results indicate that Level 2 had a large effect on growth and cost reduction, 0.422 and 0.371 respectively, whereas, it had a medium effect on differentiation and innovation at 0.274 and 0.171 respectively. For the $\mathrm{Q}^{2}$, the result shows that at Level 2 of adoption, growth (0.158), innovation (0.085), differentiation $(0.132)$ and cost reduction $(0.158)$ respectively have a satisfactory predictive relevance.

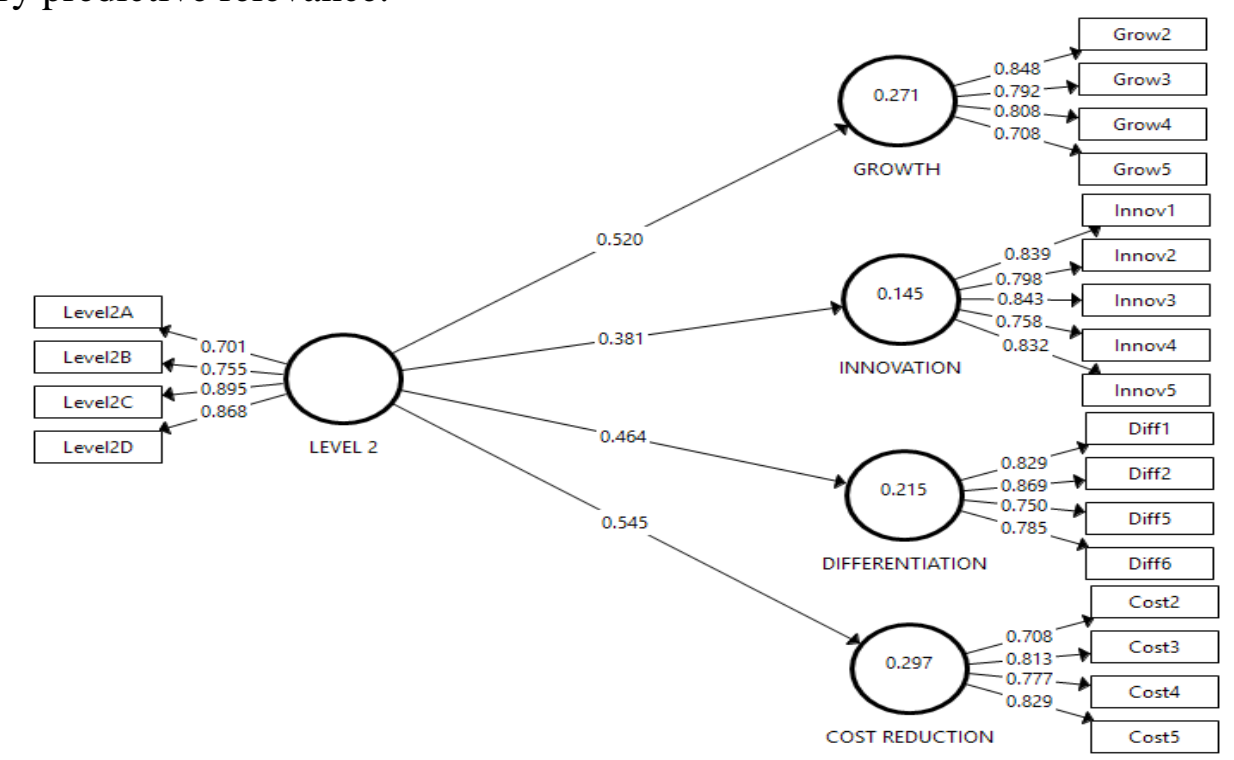

Figure 3. Structural model of Level 2

\subsubsection{Structural Model of Level 3}

A step further in the e-commerce adoption is level 3, which was on electronic transactions. This includes the firm's ability to negotiate contracts, make payment and receive payment through electronic media. This would increase a firm's sales and revenue and increases customer satisfaction that enables the SMEs to form and develop customers' intimacy (Abdelkader \& Abed, 2016; Triandini et al., 2017). Figure 4 shows Level 3 significantly and positively affected growth $(\beta=0.471, \mathrm{t}=15.274, \mathrm{p}<0.001)$, innovation $(\beta=0.379, \mathrm{t}=9.542$, $\mathrm{p}<0.001)$, differentiation $(\beta=0.450, \mathrm{t}=10.849, \mathrm{p}<0.001)$, and cost reduction $(\beta=0.567, \mathrm{t}=$ 14.465, $\mathrm{p}<0.001$ ), supporting H3. Likewise, for $\mathrm{R}^{2}$, it was found that Level 3 adoption explained $22.2 \%, 14.4 \%, 20.2 \%$, and $32.1 \%$ of the variance in growth, innovation, differentiation and cost reduction respectively. Moreover, the results show that level 3 of adoption had a large effect on cost reduction, (0.473), and medium effect on growth, (0.285), differentiation $(0.253)$ and innovation $(0.168)$ respectively. As for $\mathrm{Q}^{2}$, the results show that at Level 3 of adoption, growth (0.130), innovation (0.081), differentiation (0.119) and cost reduction $(0.186)$ respectively have a satisfactory predictive relevance. 


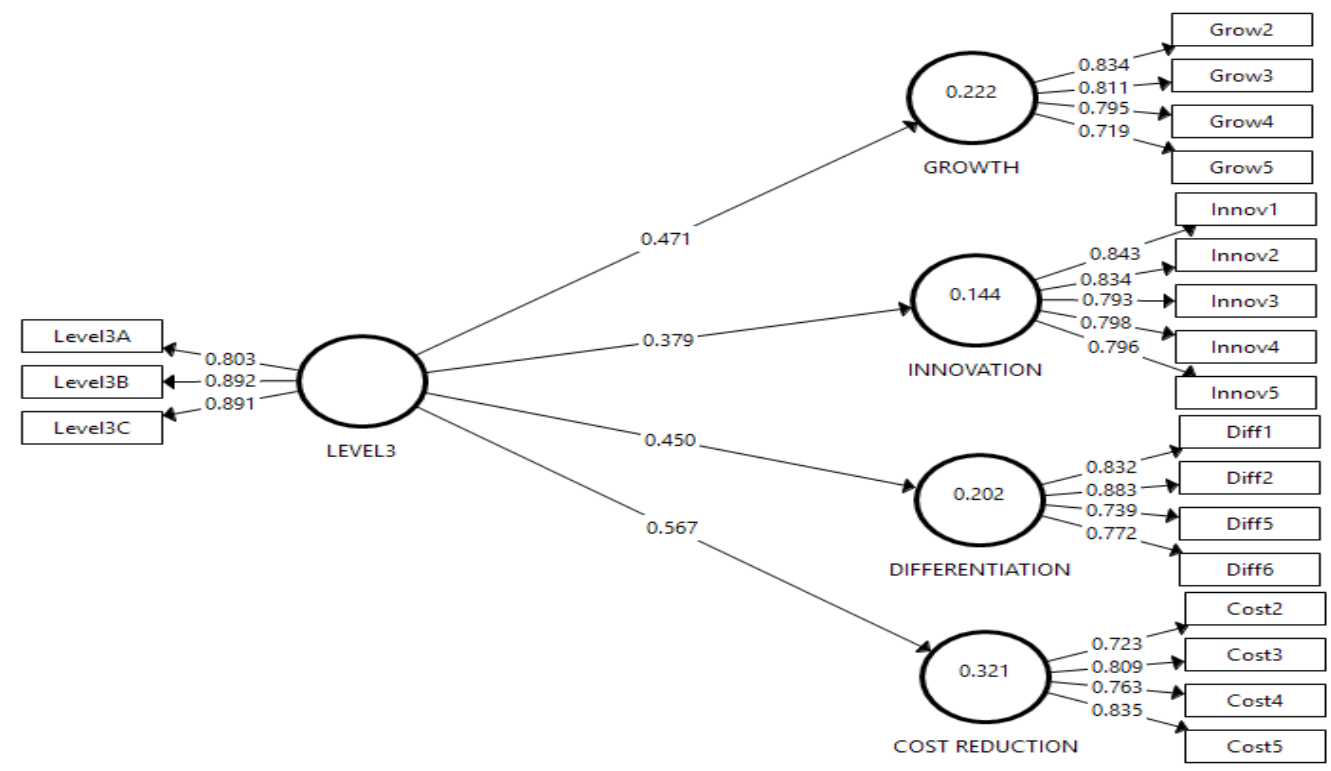

Figure 4. Structural model of Level 3

\subsubsection{Structural Model of Level 4}

The level 4 covered electronic collaboration, where the use of management information systems, extranet, and tracking of products using advanced electronic media was covered. As stated, this will increase the effectiveness and efficiency of the firms (Hazen \& Byrd, 2012). Growth is the means of enhancing business efficiency (Abdelkader \& Abed, 2016). IT adoption affects a SMEs' growth ability by increasing its scope and extending its core business through market penetration and development (Elbeltagi et al., 2016; Xu \& Quaddus, 2013). The adoption of technology can help SMEs' increase market share and effectively expand its geographical markets domestically and globally (Bhatt et al., 2017). Internet technology increases a firm's sales and revenue and increases customer satisfaction that enables an organization to form and develop customers' intimacy (Abdelkader \& Abed, 2016; Wong \& Karia, 2010). Additionally, adopting internet technologies reduced the costs of marketing, advertising and sales of products/services (Abou-Shouk et al., 2013; Belton, 2017). Under the Level 4 (Figure 5), growth $(\beta=0.539, \mathrm{t}=14.081, \mathrm{p}<0.001)$, innovation $(\beta=0.376, \mathrm{t}=7.936$, $\mathrm{p}<0.001)$, differentiation $(\beta=0.476, \mathrm{t}=10.325, \mathrm{p}<0.001)$, and cost reduction $(\beta=0.573, \mathrm{t}=$ $16.717, \mathrm{p}<0.001)$ results have a positive and significant effect on Level 4 adoption as depicted in Figure 5, supporting H4. For $\mathrm{R}^{2}$, it was found that the level of adoption explained $29.1 \%$ of the variance in growth, $14.1 \%$ of that in innovation, $22.7 \%$ of that in differentiation, and $32.9 \%$ of that in cost reduction. Also, $f^{2}$, the results indicate that the level 4 of adoption had a large effect on cost reduction and growth, and medium effect on differentiation and innovation, $0.490,0.410,0.293$ and 0.165 respectively. Additionally, in assessing the $\mathrm{Q}^{2}$, the results show that at Level 4 of adoption, growth (0.170), innovation (0.085), differentiation (0.137) and cost reduction $(0.188)$ had satisfactory predictive relevance. 


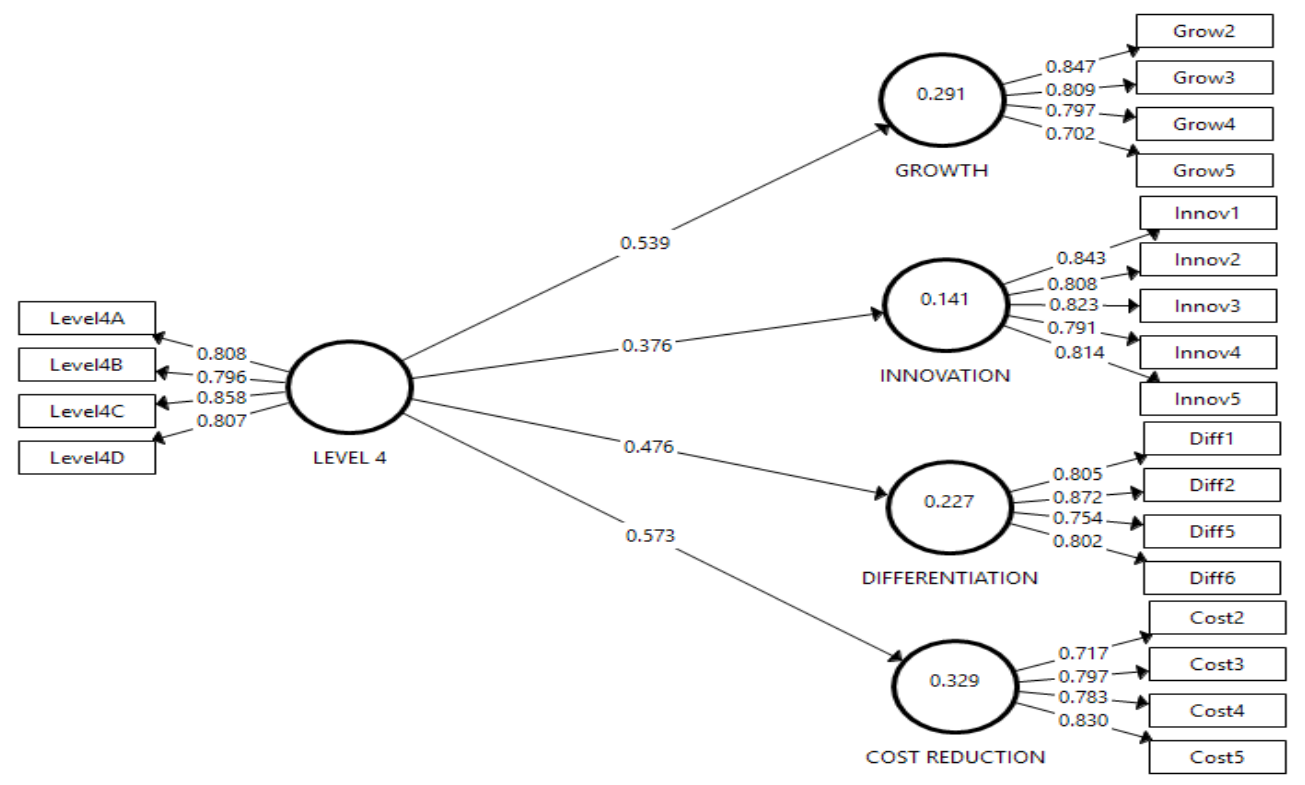

Figure 5. Structural model of Level 4

Furthermore, analysis of the composite-based standardized root mean square residual (SRMR) yielded values of 0.079, 0.080, 0.082 and 0.083 for Level 1, Level 2, Level 3 and Level 4 respectively, which are below the threshold of 0.10 , hence confirming the overall fit of the path model (Hair, Sarstedt, Ringle, \& Mena, 2012; Henseler et al., 2014).

\section{Discussion of Results}

From the results, it is clear that the Ghanaian manufacturing SMEs demonstrated significant responses on all eBPs at all four levels of B2B e-commerce adoption. At the first level of B2B2 e-commerce adoption, Ghanaian SMEs achieved growth such as an increase in market share, sales, customer satisfaction, business efficiency and access to new markets. This finding is in agreement with Hamad et al. (2018), who found that adopting B2B e-commerce helps SMEs to increase sales and enhance business efficiency. Furthermore, at the next level of B2B e-commerce adoption, the results indicated that Ghanaian SMEs achieve a higher level of growth, and particularly at level 4 , where the $\mathrm{R}^{2}$ values increase from 0.271 (level 2) to 0.291 (level 4), although, there was a slight decrease in level 3. This result shows that Ghanaian SMEs does achieve higher levels of growth when firms upgrade to higher levels. These findings are consistent with N'Da et al. (2008) and Elbeltagi et al. (2016) who found that adopting higher levels of e-commerce helps SMEs to increase revenue and growth (supporting H5).

In relation innovation, the results revealed that SMEs at the first level of adoption, achieve better coordination of business operations, changes in the way SMEs conduct business and shorten the period for product development. These results are in line with earlier studies by Teo and Pian (2003) which reported internet adoption brings innovation such as changes in the way firms conduct business rather than simply as a medium to cost reduction. Besides, at the next levels of B2B e-commerce adoption, the results revealed that Ghanaian SMEs achieve virtually same innovation advantages as obtained in level 1 , as the $\mathrm{R}^{2}$ values (a slight decrease from level 2) did not change (see Figures 3, 4 and 5). The Ghanaian SMEs remain at almost the same level of innovation, regardless of the level of adoption.

Regarding differentiation, the results of the research showed that SMEs at the first level of B2B e-commerce adoption, various forms of differentiation were obtained which include providing easier customer access to information, better and new products and services to 
customers, and improving the credibility and prestige of the firm. The SMEs also gained a form of differentiation by creating the awareness of their products and services to enhance the image of their firms. These findings are in agreement with previous investigations by Hamad et al. (2018) who found that adopting B2B e-commerce attained these forms of differentiation. When the Ghanaian SMEs upgrade to higher levels, they obtained greater levels of differentiation, which supported hypothesis $\mathrm{H} 5, \mathrm{R}^{2}$ values increases from 0.215 (level 2), to 0.202 (an increase from level 1) and 0.227 at the third and fourth levels, respectively.

Finally, at the first level of B2B e-commerce adoption, the Ghanaian SMEs achieved the competitive advantage of "cost reduction" through reducing costs in marketing, advertising, information distribution, and communication between their suppliers and customers. This is generally in line with earlier studies by Hamad et al. (2018) who found that the adoption of B2B e-commerce achieves these forms of cost reduction. This result is consistent with the previous study by Ghobakhloo et al. (2011) who found that Iranian SMEs use e-mails to satisfy their communication needs. Moreover, when the Ghanaian SMEs adopts higher levels of B2B e-commerce, they achieve higher levels of cost reduction, thus supports $\mathrm{H} 5$. The $\mathrm{R}^{2}$ values increase from 0.29.7 (level 2) to 0.32.1 and 0.32.9 at the third and fourth levels respectively. Therefore, the higher the level of $\mathrm{B} 2 \mathrm{~B}$ e-commerce adoption, the higher the level of cost reduction gained, thus supporting $\mathrm{H} 5$. These findings are congruent with that of Elbeltagi et al. (2016) and Byrd and Turner (2001) who revealed that adopting a higher level of B2B ecommerce leads to a greater competitive advantage. From the above discussion, the results showed that B2B e-commerce adoption could assist Ghanaian SMEs to gain competitive advantages. Nonetheless, considering the $\mathrm{R}^{2}$ values, the Ghanaian manufacturing SMEs achieve low levels of competitive advantage in term of growth, innovation, differentiation and cost reduction. This could be explained by that Ghanaian SMEs adopt a low level of B2B ecommerce.

\section{Conclusion}

The results from this research showed that Ghanaian manufacturing SMEs' level of B2B e-commerce adoption affects competitive advantage and each level has a significant and positive relationship with the dimensions of competitive advantage. The findings indicate that the higher the level of B2B e-commerce manufacturing SMEs adopts, the higher the degree of competitive advantage they gain. The results confirm that there are different levels of adoption among the SMEs and in turn leads to gaining different competitive advantages. The findings show that SMEs focused more on cost reduction as this permits them to save on costs in their operational activities. It allowed them to reduce costs in all business operations and communications. Growth and differentiation are the next targeted form of competitive advantage they seek to achieve. However, the overall findings revealed that Ghanaian SMEs adopt a low level of B2B e-commerce. Most Ghanaian SMEs have adopted B2B e-commerce to create awareness of their products and services generally. Though few of them support electronic payment services, the use of electronic payment services is low. The plausible reasons are that there is inadequate technological infrastructure, top managers/owners' resistance to moving from traditional methods of doing business to automated processes, and security concerns (cyber fraud, trust, and satisfaction) that accounts for the delay in adopting high technology and, in turn, gain greater competitive advantage.

The findings established that there are different levels of B2B e-commerce and different competitive advantage gained at each level of adoption. Therefore, it can be argued that this research's approach to conceptualizing the levels of B2B e-commerce adoption and competitive advantage adds to its strength and represents another contribution relevant to technology 
adoption literature. Another contribution of this research is manifested in the methodology that is based on empirical validation. The measurement model developed in this study might be useful for scholars carrying out further investigations into manufacturing SMEs adoption of B2B e-commerce and competitive advantage in the context of developing countries, particularly, Sub-Saharan Africa.

This research also has a significant implication to practice for owners/managers and policymakers. It is imperative for SME owners/managers to recognize the effect that B2B ecommerce can have on their business growth and competitiveness. SMEs that are reluctant to adopt $\mathrm{B} 2 \mathrm{~B}$ e-commerce must evaluate their decision prudently, as adopting B2B e-commerce is likely to be a requisite for today's business environment. Moreover, the study's findings show that a higher level of B2B e-commerce creates a greater competitive advantage. Likewise, technology vendors should re-strategize their services offering to meet different segments of SMEs taking into account their current level of adoption.

For policy makers, the results of this research could be used to develop more concrete policies to motivate SMEs to adopt and use a higher level of technology. Importantly, government should be more supportive through drafting policies and legislation, providing more training and education programs, and technical support to encourage SMEs in adopting technology. The government should also offer tax incentives on technology devices such as computers, servers and website designs which may accelerate B2B e-commerce adoption.

This research has certain limitations as follows. First, the study employed a quantitative method that is based on a self-administrated cross-sectional study to investigate the relationship between B2B e-commerce adoption levels and competitive advantage of Ghanaian manufacturing SMEs. This approach only reflects the respondents' beliefs, perceptions, and experiences towards the adoption of $\mathrm{B} 2 \mathrm{~B}$ e-commerce at a particular point in time. However, these can change over time which necessitates conducting a longitudinal survey in future research to provide more robust evidence. Also, the sample frame poses some constraints on the ability to generalize the results beyond the manufacturing sector for Ghana. Hence, future studies on the levels of adoption and competitive advantage should be extended to other SMEs sectors (financial and services) to add more scope in understanding the current phenomenon. A cross-country study could offer further direction for future research.

\section{Acknowledgement}

This research supported by the Humanities, Social Science Foundation of the Ministry of Education, China, under Grant [number 16YJC790031]; and National Social Science Foundation of China, under Grant [number 18BJY105].

\section{References}

Abdelkader, B., \& Abed, B. (2016). The effect of information technology on competitive advantage of firm: The role of environmental uncertainty. The International Journal of Management Science and Information Technology (IJMSIT), (22), 16-39.

Abou-Shouk, M., Megicks, P., \& Lim, W. M. (2013). Perceived benefits and E-commerce adoption by SME travel agents in developing countries: Evidence from Egypt. Journal $\begin{array}{lllll}\text { of Hospitality } \& \text { Tourism } & \text { Research, }\end{array}$ http://dx.doi.org/10.1177/1096348012442544

Al-Ghamdi, R., Alfarraj, O., \& Bahadad, A. (2014). "How Retailers at different stages of Ecommerce Maturity evaluates their entry to E-commerce activities". Journal of Computer Science and Information Technology, 2(2), 37-71. 
Al-Somali, Gholami, R., \& Clegg, B. (2011). Determinants of B2B e-commerce adoption in Saudi Arabian firms. International Journal of Digital Society (IJDS), 2(2), 406-415.

Andrew, L., \& Ab Malik, A. M. (2016). Information Technology and Competitive Advantages Among Small and Medium Enterprises in Malaysian Tourism Industry. Paper presented at the Proceedings of the 1st AAGBS International Conference on Business Management 2014 (AiCoBM 2014).

Awiagah, R., Kang, J., \& Lim, J. I. (2016). Factors affecting e-commerce adoption among SMEs in Ghana. Information Development, 32(4), 815-836. http://dx.doi.org/10.1177/0266666915571427

Beck, R., Wigand, R., \& Konig, W. (2005). The diffusion and efficient use of electronic commerce among small and medium-sized enterprises: An international three-industry

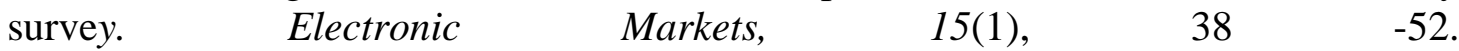
http://dx.doi.org/10.1080/10196780500035282

Belton, P. (2017). Competitive Strategy: Creating and Sustaining Superior Performance: Macat Library.

Benitez, J., Llorens, J., \& Fernandez, V. (2015). IT impact on talent management and operational environmental sustainability. Information Technology \& Management, 16(3), $207-220$.

Bhatt, G., Emdad, A., Roberts, N., \& Grover, V. (2010). Building and leveraging information in dynamic environments: The role of IT infrastructure flexibility as enabler of organizational responsiveness and competitive advantage. Information \& Management, 47(7), 341-349.

Bhatt, G.D., Wang, Z., \& Rodger, J. A. (2017). Information Systems Capabilities and Their Effects on Competitive Advantages: A Study of Chinese Companies. Information Resources Management Journal (IRMJ), 30(3), 41-57.

Bingley, S., \& Burgess, S. (2012). A case analysis of the adoption of Internet applications by local sporting bodies in New Zealand. International Journal of Information Management, 32(1), 11-16. https://doi.org/10.1016/j.ijinfomgt.2011.05.001

Breznik, L. (2012). Can information technology be a source of competitive advantage? Economic and Business Review for Central and South-Eastern Europe, 14(3), 251.

Byrd, T. A., \& Turner, D. E. (2001). An exploratory examination of the relationship between flexible IT infrastructure and competitive advantage. Information \& Management, 39(1), 41-52. http://dx.doi.org/10.1016/S0378-7206(01)00078-7

Chen, J., \& McQueen, R. (2008). An analysis of adoption motivators and inhibitors. Journal of Global Information Management, 16(null), 26. http://dx.doi.org/10.4018/JGIM

Chin. W.W. (2010). How to write up and report PLS analyses. In Handbook of partial least squares. New York: Springer.

Elbeltagi, I., Hamad, H., Moizer, J., \& Abou-Shouk, M. A. (2016). Levels of Business to Business E-Commerce Adoption and Competitive Advantage in Small and MediumSized Enterprises: A Comparison Study Between Egypt and the United States. Journal of Global Information Technology Management, 19(1), 6-25. http://dx.doi.org/10.1080/1097198X.2016.1134169

Farrell, A. M. (2010). Insufficient discriminant validity: A comment on Bove, Pervan, Beatty, and Shiu (2009). Journal of Business Research, 63(3), 324-327.

Fornell, C. \& Larcker, D. F. (1981). Evaluating structural equation models with unobservable variables and measurement error. Journal of Marketing Research, 39-50.

Gebauer, H. \& Schober, F. (2006). Information system flexibility and the cost efficiency of business processes. Journal of the Association for Information Systems, 7(3), 122 - 147. 
Ghobakhloo, M., Arias-Aranda, D., \& Benitez-Amado, J. (2011). Adoption of e-commerce applications in SMEs. Industrial Management \& Data Systems, 111(8), 1238-1269. http://dx.doi.org/10.1108/02635571111170785

Guarda, T., Augusto, M., \& Silva, C. (2012). Competitive Advantage in e-Commerce: The Case of Database Marketing. In M. Zhu (Ed.), Business, Economics, Financial Sciences, and Management (pp. 123-130). Berlin, Heidelberg: Springer Berlin Heidelberg.

Hair, J.F., Hult, G. T. M., Ringle, C., \& Sarstedt, M. (2016). A primer on partial least squares structural equation modelling (PLS-SEM): Sage Publications.

Hair, J.F., Ringle, C. M., \& Sarstedt, M. (2011). PLS-SEM: Indeed a silver bullet. Journal of Marketing theory and Practice, 19(2), 139-152. http://dx.doi.org/10.2753/MTP1069$\underline{6679190202}$

Hair, Sarstedt, Ringle, \& Mena. (2012). An assessment of the use of partial least squares structural equation modelling in Marketing research. Journal of the Academy of Marketing Science, 40(3), 414 -433.

Hamad, H., Elbeltagi, I., \& El-Gohary, H. (2018). An empirical investigation of business-tobusiness e-commerce adoption and its impact on SMEs competitive advantage: The case of Egyptian manufacturing SMEs. Strategic Change, 27(3), 209-229. http://dx.doi.org/10.1002/jsc.2196

Hazen, B. T., \& Byrd, T. A. (2012). Toward creating competitive advantage with logistics information technology. International Journal of Physical Distribution \& Logistics Management, 42(1), 8-35. http://dx.doi.org/10.1108/09600031211202454

Henseler, J., Dijkstra, T. K., Sarstedt, M., Ringle, C. M., Diamantopoulos, A., Straub, D. W., ... Calantone, R. J. (2014). Common beliefs and reality about PLS comments on Rönkkö and Evermann (2013). Organizational Research Methods, 17(2), 182-209.

Henseler, J., Hubon, G., \& Ray, A. P. (2016). "Using PLS path modelling in new technology research: updated guidelines". Industrial Management \& Data Systems, 116(1), 2-20. http://dx.doi.org/10.1108/IMDS-09-2015-0382

Henseler, J., Ringle, C. M., \& Sinkovics, R. R. (2009). The use of partial least squares path modelling in international marketing. Advances in International Marketing, 20(1), 277319. http://doi.org/10.1108/S1474-7979(2009)0000020014

Krell, \& Matook. (2009). Competitive advantage from mandatory investments: An empirical study of Australian firms. The Journal of Strategic Information Systems, 18(1), 31- 45. http://dx.doi.org/10.1016/j.jsis.2008.12.001

Lederer, Mirchandani, D. A., \& Sims, K. (1997). The link between information strategy and electronic commerce. Journal of Organizational Computing and Electronic Commerce, 7(1), 17-34. http://dx.doi.org/10.1207/s15327744joce0701_2

Lefebvre, L.-A., Lefebvre, É., Elia, E., \& Boeck, H. (2005). Exploring B-to-B e-commerce adoption trajectories in manufacturing SMEs. Technovation, 25(12), 1443-1456. http://dx.doi.org/10.1016/j.technovation.2005.06.011

Lip-Sam, T., \& Hock-Eam, L. (2011). Estimating the determinants of B2B e-commerce adoption among small \& medium enterprises. International Journal of Business and Society, 12(1), 15.

Lumpkin, G., Droege, S. B., \& Dess, G. G. (2002). E-commerce strategies: achieving sustainable competitive advantage and avoiding pitfalls. Organizational Dynamics, 30(4), 325-340. http://dx.doi.org/10.1016/S0090-2616(02)00065-7

Marinagi, C., Trivellas, P., \& Sakas, D. P. (2014). The Impact of Information Technology on the Development of Supply Chain Competitive Advantage. Procedia - Social and Behavioral Sciences, 147, 586-591. http://dx.doi.org/10.1016/j.sbspro.2014.07.161 
Molla, A., \& Licker, P. S. (2005). E-commerce adoption in developing countries: a model and instrument. Information \& Management, 42(6), 877-899. Moraisa, E. P., Piresa, J. A., \& Gonçalvesb, R. M. (2012). E-Business Maturity: Constraints associated with their evolution. Journal of Organizational Computing and Electronic Commerce, 22(3), 280 $-300$.

N'Da, K., Bergeron, F., \& Raymond, L. (2008). Achieving advantages from business-tobusiness electronic commerce: an empirical validation of an integrative framework. International Journal of Electronic Business, 6(5), 516-549. http://dx.doi.org/10.1504/IJEB.2008.021185

OECD. (2012). Financing SMEs and entrepreneurs. An OECD scoreboard. Paris: Organisation of Economic and Co-operation Development.

Pavic, S., Koh, S. C. L., Simpson, M., \& Padmore, J. (2007). Could e-business create a competitive advantage in UK SMEs? Benchmarking: An International Journal, 14(3), 320-351. http://dx.doi.org/10.1108/14635770710753112

Pilinkiene, V., Kurschus, R.-J., \& Auskalnyte, G. (2013). E-business as a source of competitive advantage. Economics and Management, 18(1), 77-85.

Porter, M. (1985). Competitive advantage: Creating and sustaining superior performance. New York, NY: Free Press.

Rahayu, R., \& Day, J. (2017). E-commerce adoption by SMEs in developing countries: evidence from Indonesia. Eurasian Business Review, 7(1), 25-41.

Rao, S., Metts, G., \& Mora Monge, C. A. (2003). Electronic commerce development in small and medium sized enterprises: A stage model and its implications. Business Process Management Journal, 9(1), 11-32.

Ringle, C. M., Wende, S., \& Becker, J. M. (2015). SmartPLS 3.

Scupola. A. (2003). The adoption of Internet commerce by SMEs in the South of Italy: An environmental, technological and organizational perspective. Journal of Global Information Technology Management, $\quad 6(1), \quad 57-71$. http://dx.doi.org/10.1080/1097198X.2003.10856343

Seongbae, L., \& Silvana, T. (2014). Impact of Information Technology Infrastructure Flexibility on the Competitive Advantage of Small and Medium Sized-Enterprises. Journal of Business \& Management, 3(1), 01-12. http://dx.doi.org/10.12735/jbm.v3i1p1

Sila, I. (2013). Factors affecting the adoption of B2B e-commerce technologies. Electronic Commerce Research, 13(2), 199-236. http://dx.doi.org/10.1007/s10660-013-9110-7

Teo, \& Pian. (2003). A contingency perspective on Internet adoption and competitive advantage. European Journal of Information Systems, 12(2), 78-92. http://dx.doi.org/10.1057/palgrave.ejis.3000448

Teo, T.S.H. \& Ranganathan, C. (2004). Adopters and non-adopters of business-to-business electronic commerce in Singapore. Information \& Management, 42(1), 89-102.

Triandini, E., Djunaidy, A., \& Siahaan, D. (2017). A maturity model for e-commerce adoption by small and medium enterprises in Indonesia. Journal of Electronic Commerce in Organizations (JECO), 12(1), 44-58

Wagner, S. M. (2006). A firm's responses to deficient suppliers and competitive advantage. $\begin{array}{llll}\text { Journal of Business } & \text { Research, 686-695. }\end{array}$ http://dx.doi.org/10.1016/j.jbusres.2006.01.006

Wong, C.Y, \& Karia, N. (2010). Explaining the competitive advantage of logistics service providers: A resource-based view approach. International Journal of Production Economics, 128(1), $51-67$. 
Xu, J., \& Quaddus, M. (2013). Information systems for competitive advantages Managing Information Systems (pp. 27-40): Springer.

Zandi, F. (2013). A Country-Level Decision Support Framework for Self-Assessment of ECommerce Maturity. iBusiness, 5(2), 43 -54.

\section{APPENDIX A}

Measurement items of B2B e-commerce adoption levels

\begin{tabular}{|c|c|c|}
\hline Constructs name & Description & Items \\
\hline \multirow{4}{*}{$\begin{array}{l}\text { Electronic information } \\
\text { (Level 1) }\end{array}$} & Providing general information about the firm & Level1A \\
\hline & Promoting the firm's products and services & Level1B \\
\hline & $\begin{array}{l}\text { Communicating and responding with suppliers and } \\
\text { customers by email }\end{array}$ & Level1C \\
\hline & Seeking out new customers and suppliers & Level1D \\
\hline \multirow[t]{4}{*}{$\begin{array}{l}\text { Electronic interaction } \\
\text { (Level 2) }\end{array}$} & $\begin{array}{l}\text { Responding to customers and suppliers' enquiries } \\
\text { and feedback }\end{array}$ & Level2A \\
\hline & Placing and managing orders with suppliers & Level2B \\
\hline & Receiving and managing orders with customers & Level2C \\
\hline & Offering customers, after-sales service & Level2D \\
\hline \multirow{3}{*}{$\begin{array}{l}\text { Electronic transaction } \\
\text { (Level 3) }\end{array}$} & Receiving electronic payments from customers & Level3A \\
\hline & Making electronic payments to suppliers & Level3B \\
\hline & $\begin{array}{l}\text { Negotiating contracts (price, volume) with suppliers } \\
\text { and customers }\end{array}$ & Level3C \\
\hline \multirow[t]{4}{*}{$\begin{array}{l}\text { Electronic collaboration } \\
\text { (Level 4) }\end{array}$} & $\begin{array}{l}\text { Using management information systems to enhance } \\
\text { quality assurance }\end{array}$ & Level4A \\
\hline & Using extranet to communicate with key suppliers & Level4B \\
\hline & $\begin{array}{l}\text { Transferring documents and technical drawing to } \\
\text { suppliers }\end{array}$ & Level4C \\
\hline & $\begin{array}{l}\text { Tracking products (purchased and sold) during } \\
\text { transportation }\end{array}$ & Level4D \\
\hline
\end{tabular}

